IRA-International Journal of Applied Sciences ISSN 2455-4499; Vol.05, Issue 03 (2016)

Institute of Research Advances

Pg. no. 122-128

http://research-advances.org/index.php/IRAJAS

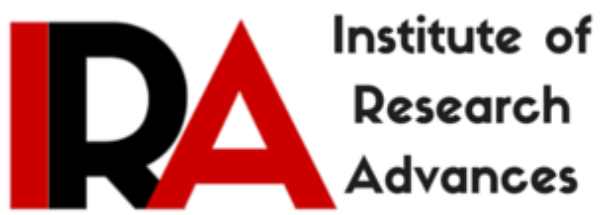

\title{
An Approach towards the Determination of Alkalinity in Water, Its Experimental Consideration \& Comparison with Traditional Method: An Overview
}

\author{
Harshit Sharma $^{1}$ and Richa Saxena ${ }^{2}$ \\ ${ }^{1,2}$ Institute of Technology \& Management, \\ Gwalior, M.P., India.
}

Type of Review: Peer Reviewed.

DOI: http://dx.doi.org/10.21013/jas.v5.n3.p3

\section{How to cite this paper:}

Sharma, H., \& Saxena, R. (2016). An Approach towards the Determination of Alkalinity in Water, Its Experimental Consideration \& Comparison with Traditional Method: An Overview. IRA-International Journal of Applied Sciences (ISSN 2455-4499), 5(3), 122-128. doi:http://dx.doi.org/10.21013/jas.v5.n3.p3

(C) Institute of Research Advances

\section{(cc) EY-NC}

This work is licensed under a Creative Commons Attribution-Non Commercial 4.0 International License subject to proper citation to the publication source of the work.

Disclaimer: The scholarly papers as reviewed and published by the Institute of Research Advances (IRA) are the views and opinions of their respective authors and are not the views or opinions of the IRA. The IRA disclaims of any harm or loss caused due to the published content to any party. 


\section{ABSTRACT}

Alkalinity is equal to the stoichiometric sum of the bases in solution therefore it includes all the acid neutralizing bases in water namely $\mathrm{OH}^{-}, \mathrm{CO}_{3}{ }^{2-} \& \mathrm{HCO}_{3}{ }^{-}$ions. In the natural environment carbonate alkalinity tends to make up most of the total alkalinity due to the common occurrence and dissolution of carbonate rocks and presence of $\mathrm{CO}_{2}$ in the atmosphere. Alkalinity varies with the location Acid-base titration is performed for their estimation but the theoretical determination for the type and extent of these ions is tedious process through traditional formulas known to us, (Volume of acid used up till Phenolphthalein \& Methyl orange end point). Here in this paper we are trying to simplify the method and reporting the direct determination of the extent of ions by simple calculation without using the formulas for specific ions under different conditions of alkalinity. Thus a comparative aspect of this approach with traditional method will be covered by us in this paper.

Key words: Alkalinity, acid-base titration, ions, phenolphthalein, methyl orange indicator.

\section{Introduction}

Alkalinity is primarily a way of measuring the acid neutralizing capacity of water. In other words, it is ability to maintain a relatively constant $\mathrm{pH}$, the possibility to maintain constant $\mathrm{pH}$ is due to the hydroxyl, carbonate and bicarbonate ions present in water.The ability of natural water to act as a buffer is controlled in part by the amount of calcium and carbonate ion in solution. Both carbonate and calcium ion come from calcium carbonate or limestone so water that comes in contact with limestone will contain high levels of both $\mathrm{Ca}^{2+}$ and $\mathrm{CO}_{3}{ }^{2-}$ ions and have elevated hardness and alkalinity.Alkalinity or "acid neutralizing capacity," is measured by adding acid to the sample and figuring out the equivalent alkalinity in the water. The actual units for the alkalinity titration are moles or equivalents per volume (moles/L or eq/L), however converting alkalinity from equiv./L to "mg/L as $\mathrm{CaCO}_{3}$ " takes into account that one mole of carbonate $\left(\mathrm{CO}_{3}{ }^{2-}\right)$ can neutralize 2 moles of acid $\mathrm{H}^{+}$.

The present piece of work highlights the simple method to determine the alkalinity of sample by simple calculation and it also covers the range which gives an idea about the type of ions which could be present.

\section{Materials and Methods}

The alkalinity of water is determined by titrating the water sample with Standard acid solution $(\mathrm{HCl})$.Alkalinity of water is attributed to the presence ofOH${ }^{-}, \mathrm{CO}_{3}{ }^{--}$and $\mathrm{HCO}_{3}{ }^{-}$ions.

The titration is performed volumetrically using phenolphthalein and methyl orange indicators. In volumetric analysis phenolphthalein end point indicates alkalinity due toOH $\mathrm{H}^{-}$ions and one half of $\mathrm{CO}_{3}{ }^{2-}$ ions i.e. completion of reactions (a) and (b) only whilst methyl orange end point marks the presence of carbonate and bicarbonate ions i.e. Completion of reactions (a), (b) and (c). Total amount of acid used represents the total alkalinity.

(a) $\left[\mathrm{OH}^{-}\right]+\left[\mathrm{H}^{+}\right]----\mathrm{H}_{2} \mathrm{O}$

(b) $\left[\mathrm{CO}_{3}{ }^{2-}\right]+\left[\mathrm{H}^{+}\right]----\mathrm{HCO}_{3}{ }^{-}$

(c) $\left[\mathrm{HCO}_{3}^{-}\right]+\left[\mathrm{H}^{+}\right]----\mathrm{H}_{2} \mathrm{O}+\mathrm{CO}_{2}$

$\left[\mathrm{H}^{+}\right]$corresponds to standard $\mathrm{HCl}$ while hydroxide, carbonate and bicarbonate are the alkalinity causing ions present in water.

Five different samples of alkaline water (having 5 possible combination of ions in water) was prepared and titrated to obtain the volume of acid till P \& M end point 
TABLE-1

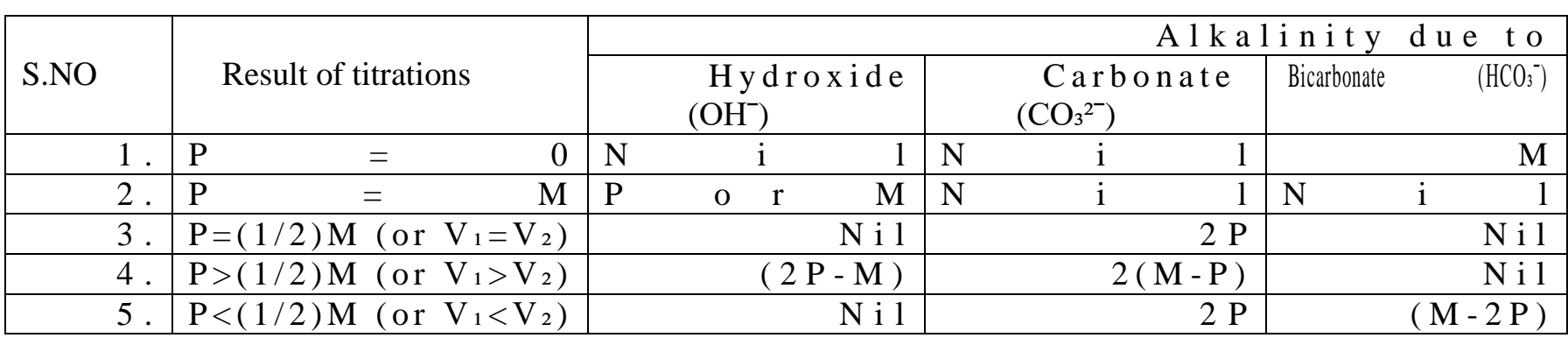

This table has the formulas for calculating the extent of ions which is difficult to remember.

\section{Results \& Discussion}

Alkalinity or "acid neutralizing capacity," is measured by adding acid to the sample and figuring out the equivalent alkalinity in the water. The actual units for the alkalinity titration are moles or equivalents per volume (moles/L or eq/L), however converting alkalinity from equiv./L to "mg/L as $\mathrm{CaCO}_{3}$ " takes into account that one mole of carbonate $\left(\mathrm{CO}_{3}{ }^{2-}\right)$ can neutralize 2 molesof acid $\mathrm{H}^{+}$. Determining the extent of ions through the reported formulas for different conditions, mentioned in the Table-1 is difficult. Thus herein we report different conditions \& method to determine the extent of ions directly from the values without using the formulas. Different cases with suitable examples are explained below.

The procedure described here is simple making it a preferred method for calculating alkalinity. The method is reliable as could be observed from the results obtained through the quoted examples.

Table: 2. FOR SEPARATE TITRATION

(Different aliquot of water sample for $\mathrm{P} \& \mathrm{M}$ end point determination)

\begin{tabular}{|l|l|l|l|}
\hline \multicolumn{1}{|c|}{$\mathrm{OH}^{-}$} & \multicolumn{1}{c|}{$\mathrm{CO}_{3}{ }^{2-}$} & $\mathrm{HCO}_{3}{ }^{-}$ \\
\hline & \multicolumn{1}{|c|}{} & Nil & Nil \\
\hline 2. & V1 or 2$) \mathrm{ml}$ & Nil & V2 ml \\
\hline 3. & Nil & $(2 \mathrm{~V} 1$ or V2) $\mathrm{ml}$ & Nil \\
\hline 4. & Nil & $2 \mathrm{~V} 1 \mathrm{ml}$ & $(\mathrm{V} 2-2 \mathrm{~V} 1) \mathrm{ml}$ \\
\hline 5 & $\{\mathrm{~V} 1-(\mathrm{V} 2-\mathrm{V} 1)\} \mathrm{ml}$ & $2(\mathrm{~V} 2-\mathrm{V} 1) \mathrm{ml}$ & $\mathrm{Nil}$ \\
\hline
\end{tabular}

Table: 3. FOR SINGLE/SAME TITRATION

(Same aliquot of watersample for $\mathrm{P} \& \mathrm{M}$ end point determination)

\begin{tabular}{|l|l|l|l|}
\hline \multicolumn{2}{|c|}{$\mathrm{OH}^{-}$} & \multicolumn{1}{c|}{$\mathrm{CO}_{3}{ }^{2-}$} & $\mathrm{HCO}_{3}{ }^{-}$ \\
\hline 1. & Nil & $(2 \mathrm{~V} 1$ or 2V2) $\mathrm{ml}$ & Nil \\
\hline 2. & Nil & $2 \mathrm{~V} 1$ & $(\mathrm{~V} 2-\mathrm{V} 1) \mathrm{ml}$ \\
\hline 3. & $(\mathrm{~V} 1-\mathrm{V} 2) \mathrm{ml}$ & $2 \mathrm{~V} 2$ & Nil \\
\hline
\end{tabular}

Where, $V_{1}$ is the volume of acid required used with phenolphthalein indicator, while $V_{2}$ is the volume used with methyl orange indicator. 
Table $2 \& 3$ summarize the volume of acid used for separate and single water sample titration till $\mathrm{P}$ and $\mathrm{M}$ end point. This simplifies our task of calculating the strength by identifying the volume of acid consumed instead of putting the traditional formulas.

\section{CASE: 1}

For $\mathrm{HCO}_{3}{ }^{-}$only:

When there is no change in color on adding phenolphthalein indicator it indicates the presence of only $\mathrm{HCO}_{3}{ }^{-}$in water sample. So the volume of acid required for complete neutralization of $\mathrm{HCO}_{3}{ }^{-}$will be equal to the volume of acid used for complete neutralization of $\mathrm{HCO}_{3}{ }^{-}$when methyl orange is taken for titration.

Strength of $\mathrm{HCO}_{3}{ }^{-}=[\mathrm{V} * \mathrm{~N}($ acid $) * 50 * 1000] /$ volume of water sample

Where $\mathrm{V}$ is the volume of acid used for complete neutralization of $\mathrm{HCO}_{3}{ }^{-}$when methyl orange is taken for titration.

CASE: 2

For $\mathrm{OH}^{-}$only:

When the volume of acid required for complete neutralization of ion by separate titration with methyl orange and phenolphthalein indicator is same, thenit indicates the presence of onlyOH $\mathrm{H}^{-}$ion in water sample.

If $\mathrm{V}_{1}$ is the volume of acid used for complete neutralization of $\mathrm{OH}^{-}$using phenolphthalein as indicator and same volume $\mathrm{V}_{2}$ of acid used for neutralization when titration is done separately by taking another lot of water sample using methyl orange as indicator.

$\mathrm{OH}^{-}$alkalinity $=\left[\left(\mathrm{V}_{1}\right.\right.$ or $\left.\left.\mathrm{V}_{2}\right) * \mathrm{~N}(\mathrm{acid}) * 50 * 1000\right] /$ volume of water sample

Where $\mathrm{V}_{1}$ or $\mathrm{V}_{2}$ is equal to volume of acid used for neutralization of $\mathrm{OH}^{-}$using either phenolphthalein or methyl orange indicator.

\section{CASE: 3}

For $\mathrm{CO}_{3}{ }^{2-}$ only:

When the volume of acid required using methyl orange indicator is double, to the volume used using phenolphthalein indicator (in separate titration). However in single/same titration if $\left(\mathrm{V}_{1}\right)$ be the volume of acid required for half neutralization of $\mathrm{CO}_{3}{ }^{2-}$ ions with phenolphthalein indicator and the further volume of acid $\left(\mathrm{V}_{2}\right)$ in same water sample with methyl orange indicator is utilized for neutralization of $\mathrm{HCO}_{3}{ }^{-}$generated by $\mathrm{CO}_{3}{ }^{2-}$ and these two volumes of acid will be same (in same or single titration).

$\mathrm{CO}_{3}{ }^{2-}+\mathrm{H}^{+}=\mathrm{HCO}_{3}{ }^{-} \mathrm{V}_{1} \mathrm{ml}(\mathrm{ph})$

$\mathrm{HCO}_{3}{ }^{-}+\mathrm{H}^{+}=\mathrm{H}_{2} \mathrm{O}+\mathrm{CO}_{2} \mathrm{~V}_{2} \mathrm{ml}(\mathrm{Mo})$

$\mathrm{V}_{1}=\mathrm{V}_{2}$

$\mathrm{CO}_{3}{ }^{2^{-}}$alkalinity $=\left[\left(\right.\right.$volume of acid used by $\left.\mathrm{CO}_{3^{2}}{ }^{2^{-}}\right)$or $\left(\mathrm{V}_{1}\right.$ or $\left.\mathrm{V}_{2}\right) * \mathrm{~N}($ acid $\left.) * 50 * 1000\right] /$ Volume of water sample 


\section{CASE: 4}

For both $\mathrm{CO}_{3}{ }^{2-} \& \mathrm{HCO}_{3}^{-}$:

When the volume of acid required for neutralization of $\mathrm{CO}_{3}{ }^{2-}$ is $\mathrm{V}_{1}$ while $\mathrm{V}_{2}$ represent the volume of acid that is required for neutralization of $\mathrm{HCO}_{3}{ }^{-}$generated by $\mathrm{CO}_{3}{ }^{2-}$ as well as by those which are already there in water. Thus in this case $\mathrm{V}_{1}>\mathrm{V}_{2}$

$\mathrm{CO}_{3}{ }^{--}+\mathrm{H}^{+}=\mathrm{HCO}_{3}{ }^{-} \mathrm{V}_{1} \mathrm{ml}(\mathrm{ph})$

$\mathrm{HCO}_{3}{ }^{-}$(generated by $\left.\mathrm{CO}_{3}{ }^{2-}\right)+\mathrm{HCO}_{3}{ }^{-}$(initially present in water) $+\mathrm{H}^{+}=\mathrm{H}_{2} \mathrm{O}+\mathrm{CO}_{2} \mathrm{~V}_{2} \mathrm{ml}(\mathrm{Mo})$

$\mathrm{CO}_{3}{ }^{2^{-}}$alkalinity $=\left[\left(\right.\right.$Twice the volume of acid used for neutralization ofCO $\left.3^{2^{-}}\right)$or $\left.\left(2 \mathrm{~V}_{1}\right) * \mathrm{~N}(\mathrm{acid}) * 50 * 1000\right] /$ Volume of water sample

$\mathrm{HCO}_{3}{ }^{-}$alkalinity $=\left[\left(\right.\right.$volume of acid used byHCO$\left._{3}{ }^{-}\right)$or $\left(\mathrm{V}_{2}-\mathrm{V}_{1}\right) * \mathrm{~N}($ acid $\left.) * 50 * 1000\right] /$ volume of water sample

Let us consider this case through an example in which on titration of $100 \mathrm{ml}$ of water sample with N/50 $\mathrm{HCl} 5 \mathrm{ml}$ of the acid was required uptill phenolphthalein end point. Which on adding a few drops of methyl orange to the same solution and titration was further continued, the yellow color of the solution just turned pink after the addition of another $12 \mathrm{ml}$ of acid. The type and extent of alkalinity present in given water sample can be calculated by.

$\mathrm{V}_{1}=5 \mathrm{ml}$ and $\mathrm{V}_{2}=12 \mathrm{ml}$

Volume of $\mathrm{CO}_{3}{ }^{-2}=2 \mathrm{~V}_{1}=10 \mathrm{ml}$

Volume of $\mathrm{HCO}_{3}{ }^{-}=\mathrm{V}_{2}-\mathrm{V}_{1}=7 \mathrm{ml}$

Volume of water sample $=200 \mathrm{ml}$

$\mathrm{CO}_{3}{ }^{2-}$ alkalinity $=\left[\left(\right.\right.$ volume of acid used byCO $\left.{ }_{3}{ }^{2-}\right)$ or $\left(2 \mathrm{~V}_{1}\right) * \mathrm{~N}($ acid $\left.) * 50 * 1000\right] /$ volume of water sample

$$
=[10 * 1 / 50 * 50 * 1000] / 100
$$

$$
=100 \mathrm{ppm}
$$

$\mathrm{HCO}_{3}{ }^{-}$alkalinity $=\left[\left(\right.\right.$volume of acid used byHCO$\left.{ }_{3}^{-}\right)$or $\left(\mathrm{V}_{2}-\mathrm{V}_{1}\right) * \mathrm{~N}($ acid $\left.) * 50 * 1000\right] /$ volume of water sample

$$
\begin{gathered}
=[7 * 1 / 50 * 50 * 1000] / 100 \\
=70 \mathrm{ppm}
\end{gathered}
$$

\section{CASE: 5}

For both $\mathrm{OH}^{-}$and $\mathrm{CO}_{3}{ }^{2-}$

When $\mathrm{V}_{1}$ is the volume of acid required for complete neutralization of $\mathrm{OH}^{-}$\& half neutralization of $\mathrm{CO}_{3}{ }^{2-}$, and $\mathrm{V}_{2}$ is the volume of acid required to further neutralize the product of $\mathrm{CO}_{3}{ }^{2-}$ i.e. $\mathrm{HCO}_{3}{ }^{-}$will be equal to the volume of acid require by half neutralization of $\mathrm{CO}_{3}{ }^{2-}$.

$\left.\mathrm{OH}^{-}+\mathrm{H}^{+}=\mathrm{H}_{2} \mathrm{O}, \mathrm{CO}_{3}^{2^{-}}+\mathrm{H}^{+}=\mathrm{HCO}_{3}^{-}\right\} \mathrm{V}_{1} \mathrm{ml}$ (phenolphthalein indicator)

$\left.\mathrm{HCO}_{3}{ }^{-}+\mathrm{H}^{+}=\mathrm{H}_{2} \mathrm{O}+\mathrm{CO}_{2}\right\} \mathrm{V}_{2} \mathrm{ml}$ (Methyl orange indicator)

Volume of $\mathrm{CO}_{3}{ }^{2^{-}}=2 \mathrm{~V}_{2} \mathrm{ml}$ 
Volume of $\mathrm{OH}^{-}=\mathrm{V}_{1}-\mathrm{V}_{2} \mathrm{ml}$

$\mathrm{OH}^{-}$Alkalinity $=\left[\left(\right.\right.$volume of acid used by $\left.\mathrm{OH}^{-}\right)$or $\left(\mathrm{V}_{1}-\mathrm{V}_{2}\right) * \mathrm{~N}($ acid $\left.) * 50 * 1000\right] /$ volume of water sample $\mathrm{CO}_{3}{ }^{2-}$ alkalinity $=\left[\left(\right.\right.$ volume of acid used by $\left.\mathrm{CO}_{3^{2-}}\right)$ or $\left(2 \mathrm{~V}_{2}\right) * \mathrm{~N}($ acid $\left.) * 50 * 1000\right] /$ volume of water sample.

Let us consider this case through an example in which titration of $100 \mathrm{ml}$ of water sample with $20 \mathrm{ml}$ of N/50 sulphuric acid was required up till phenolphthalein end point. After this on adding a few drops of methyl orange to the same solution and further acid required was $15 \mathrm{ml}$. The type and extent of the alkalinity present in given the water sample can be calculated as follows.

Volume of $\mathrm{CO}_{3}{ }^{2^{-}}=2 \mathrm{~V}_{2} \mathrm{ml}=30 \mathrm{ml}$

Volume of $\mathrm{OH}^{-}=\mathrm{V}_{1}-\mathrm{V}_{2} \mathrm{ml}=(20-15) \mathrm{ml}=5 \mathrm{ml}$

$\mathrm{OH}^{-}$alkalinity $=\left[\left(\right.\right.$volume of acid used by $\left.\mathrm{OH}^{-}\right)$or $\left(\mathrm{V}_{1}-\mathrm{V}_{2}\right) * \mathrm{~N}($ acid $\left.) * 50 * 1000\right] /$ volume of water sample $=[5 * 1 / 50 * 50 * 1000] / 100$ $=50 \mathrm{ppm}$

$\mathrm{CO}_{3}{ }^{2^{-}}$alkalinity $=\left[\left(\right.\right.$volume of acid used by $\left.\mathrm{CO}_{3}{ }^{2-}\right)$ or $\left(2 \mathrm{~V}_{2}\right) * \mathrm{~N}($ acid $\left.) * 50 * 1000\right] /$ volume of water sample

$$
\begin{aligned}
& =[30 * 1 / 50 * 50 * 1000] / 100 \\
& =300 \mathrm{ppm}
\end{aligned}
$$

\section{Conclusion}

On the basis of above observation it could be concluded that the type and extent of alkalinity in water sample could be determined by titrating an aliquot of the water sample with standard acid to phenolphthalein end point $[\mathrm{P}]$, and continuing the titration to methyl orange end point $[\mathrm{M}]$.

Determination of alkalinity is important as alkaline water may result in caustic embritlement, it may also cause deposition of scale and sludge in boiler tubes and pipes due to which efficiency of boiler decreases.

The limitations of the traditional method (which utilizes the formulas for calculating the different possible combination of ions) and comparison of it with the direct methods of calculating ions in water has been reported in this paper.For the last two conditions having two ions $\left(\mathrm{OH}^{-}, \mathrm{CO}^{{ }^{2-}}\right) \&\left(\mathrm{CO}_{3^{2-}}\right.$, $\left.\mathrm{HCO}_{3}{ }^{-}\right)$a range is established which further helps in identification of these combination. Thus for $\mathrm{OH}^{-} \&$ $\mathrm{CO}_{3}{ }^{2^{-}}$combination (when separate water sample is taken for $\mathrm{P} \& \mathrm{M}$ end point) the minimum difference in the volume of acid consumed numerically is 1 , while the maximum difference is less than or equal to $(<=)$ half of the volume of acid used till phenolphthalein end point. While for single water sample titration the volume of acid used till $\mathrm{P}$ end point is greater than the volume of acid till M.O. end point.

However for $\mathrm{CO}_{3}{ }^{2-}$ and $\mathrm{HCO}_{3}{ }^{-}$combination, volume of acid used till $\mathrm{M}$ end point will be greater than twice the volume used till $\mathrm{P}$ end point, for separate titration while for single titration the volume of acid used till $\mathrm{M}$ end point will be greater than that used till $\mathrm{P}$ end point. 


\section{References}

1. Benjamin, Mark. Water Chemistry. New York: McGraw-Hill, 2002.

2. Giller, Paul S. and Malmqvist, Bjorn. 1998. "The Biology of Streams and Rivers." Oxford UniversityPress.

3. "PH and Alkalinity" CELS, NRS, Rhodeisland, Kellyaddy, lindagreen, Elizabethherron, URIWW3 ,july 2003

4 United States Geological Survey (USGS)1998. "National Field Manual for the Collection of WaterQuality Data."

5. U.S. EPA Office of Water, Current Drinking Water Standards. http://www.epa.gov/safewater/mcl.html 6. Standard methods for the examination of water and waste water, 17th edition. American Public HealthAssociation; American Water Works Association; and Water Pollution Control Federation, U.S.A.

7. Test procedures in accordance to ISO:3025 ( part -23) Reaffirmed 2003 